\title{
Joint IODP-ICDP Workshop Examines Challenges of Fault Zone Drilling
}

\section{Introduction}

This decade will likely be regarded in the geosciences as a time of an unprecedented explosion of fault zone drilling projects. The past few years have seen the initiation of projects including the Nojima Fault Drilling, San Andreas Fault Observatory at Depth (SAFOD), the Taiwan Chelungpu Fault Drilling Project (TCDP), the Gulf of Corinth Rift Laboratory (CRL) on land, and the Nankai Trough Seismogenic Zone Experiment (NanTroSEIZE) and Costa Rica Seismogenesis Project (CRISP) at sea (see Table 1 for references).

Each of these projects has unique objectives and scientific drivers, yet they share the fundamental goal of seeking direct access to zones of active faulting, particularly ones that generate earthquakes or have hosted seismic slip. This burgeoning interest in active fault drilling is taking place in the context of very rapidly growing research efforts on the mechanics and dynamics of faulting processes, integrating rock mechanics, seismology, geodesy, frictional physics, and fluid-fault interactions. There is a widespread recognition that our science lacks an integrated theory and understand- ing of the fundamental processes governing earthquakes and fault behavior, and the factors that control their natural variability.

On 23-26 May 2006, eighty scientists and engineers from around the world gathered for the IODP-ICDP Workshop on Fault Zone Drilling: Developing a Global Perspective in Miyazaki City on the island of Kyushu, Japan to explore the common ground-as well as the unique aspects-of all of these projects and to develop a consensus on the state of understanding of faults in the shallow crust and challenges to target in future work. The group represented a very broad spectrum in the Earth sciences, including seismologists, rock mechanicists, structural geologists, instrumentation specialists, geochemists, and many other specialties.

We have had over a century of detailed surface seismological observations, laboratory friction studies, geological observations, and case histories of earthquakes, yet processes acting at the fault interface remain elusive-because they occur deep in the subsurface, because faults are inherently heterogeneous materials, and because the initiation and propagation of fault rupture take place through complex and commonly non-linear physical processes. The physics of

Table 1. Major Currently-Active Fault Zone Drilling Projects.

\begin{tabular}{|c|c|c|c|c|}
\hline Project & Location/Earthquake & Tectonic Setting & Principal Funding Agency & Overview Reference \\
\hline $\begin{array}{l}\text { SAFOD: San Andreas Fault } \\
\text { Observatory at Depth }\end{array}$ & $\begin{array}{l}\text { San Andreas Fault } \\
\text { California, U.S.A. }\end{array}$ & Continental transform & NSF-EarthScope and ICDP & Zoback et al., 2006 \\
\hline $\begin{array}{l}\text { TCDP: Taiwan Chelungpu } \\
\text { Fault Drilling Project }\end{array}$ & $\begin{array}{l}\text { Chelungpu Fault Taiwan } \\
\text { ROC } 1999 \text { Chi-Chi M } 7.6\end{array}$ & $\begin{array}{l}\text { Arc-continent collisional } \\
\text { thrust }\end{array}$ & $\begin{array}{l}\text { Taiwan, Japan-MEXT, and } \\
\text { ICDP }\end{array}$ & Ma et al., 2006 \\
\hline $\begin{array}{l}\text { CRL: Gulf of Corinth Rift } \\
\text { Laboratory }\end{array}$ & $\begin{array}{l}\text { Helike Fault Zone Corinth, } \\
\text { Greece }\end{array}$ & Continental back arc rift & $\begin{array}{l}\text { EESD-European Union and } \\
\text { ICDP }\end{array}$ & Cornet et al., 2004 \\
\hline $\begin{array}{l}\text { NanTroSEIZE: Nankai } \\
\text { Trough Seismogenic Zone } \\
\text { Experiment }\end{array}$ & $\begin{array}{l}\text { Nankai Trough, } \\
\text { Southwestern Japan }\end{array}$ & $\begin{array}{l}\text { Subduction zone } \\
\text { megathrust }\end{array}$ & IODP & $\begin{array}{l}\text { Tobin and Kinoshita, } \\
2006\end{array}$ \\
\hline Nojima Fault Drilling & $\begin{array}{l}1995 \text { Kobe Earthquake, } \\
\text { Kobe, Japan }\end{array}$ & Continental transform & NIED, GSJ, Universites & $\begin{array}{l}\text { Ito et al., 1999, } \\
\text { Oshiman et al., } 2001\end{array}$ \\
\hline NELSAM and SeeSA & $\begin{array}{l}\text { Mining-induced seismicity } \\
\text { in South African Mines }\end{array}$ & $\begin{array}{l}\text { Intraplate, reactivated } \\
\text { faults }\end{array}$ & $\begin{array}{l}\text { ICDP, NSF, NRF South } \\
\text { Africa, MEXT }\end{array}$ & $\begin{array}{l}\text { Reches et al., 2006, } \\
\text { Ogasawara et al., this } \\
\text { issue }\end{array}$ \\
\hline $\begin{array}{l}\text { CRISP: Costa Rica } \\
\text { Seismogenesis Project }\end{array}$ & Costa Rica & $\begin{array}{l}\text { Erosional subduction } \\
\text { zone }\end{array}$ & IODP & Ranero et al., this issue \\
\hline $\begin{array}{l}\text { GONAF: Geophysical } \\
\text { Observatory on the North } \\
\text { Anatolian Fault }\end{array}$ & $\begin{array}{l}\text { North Anatolian Fault, } \\
\text { Marmara Sea, Turkey }\end{array}$ & Continental transform & ICDP (workshop) & Dresen et al., this issue \\
\hline
\end{tabular}


faulting in the crust, including the entire spectrum from aseismic creep through transient slow slip to rapid seismic slip, is a fundamental Earth process but one for which no integrated theory exists. Seismology, laboratory experiments in mechanics and friction, theoretical and modeling efforts, and fault zone geology and hydrology have all led to an understanding of the complexity of faulting and to hypotheses for many of the important processes. Testing of many of these ideas requires direct access to the actual active faults in the subsurface to collect new types of data that cannot be obtained by other means (e.g., Mori, this issue). This gap is the source of the need for the present rapid expansion of fault zone drilling.

Fault zone drilling projects are quite different in many respects from most other scientific drilling efforts. While a climate history project, for example, focuses mainly on acquiring a complete stratigraphy in cores and logs, fault zone projects target very specific zones for both coring and downhole measurements. In general, fault zone targets include discontinuities and small anomalous intervals in large rock volumes, rather than the stratigraphic column or broader rock volume of many other projects. The targets of interest are often the exact locations of poorest drilling conditions, such as a highly-fractured damage and gouge zone with potential for excess pore pressure above hydrostatic condition, anomalous stress state, weak rock, and other drilling hazards (Higuchi and Kobayashi; and Prevedel; this issue). The scientific approach commonly focuses on obtaining very extensive downhole measurements, logs, cores, and seismic structure in and around these fault zone environments. Measurements at the time of drilling as well as longterm observations are emphasized. All of these activities are technically very demanding, and in some cases they diverge from "standard" industrial borehole practice, so that creative new uses of existing technology or development of new technology is required.

\section{Science Drivers for Fault Zone Drilling}

Understanding the complex physics of tectonic faulting, earthquakes, and the generation of tsunami in the Earth's crust is among the grand remaining challenges of the geosciences. Because earthquakes take place deep below the Earth's surface, direct observation of processes acting in the faults themselves has generally not been possible; what we know about earthquake processes is derived from seismologic observations, geodetic deformation, and studies of exhumed rocks containing products of slip at depth long ago. Researchers have learned and inferred a great deal from these studies, but they are inherently limited. Much of fault zone drilling is aimed at understanding earthquake slip, but in fact fault physics encompasses a spectrum of slip and slip rates ranging from purely aseismic behavior, such as steady creep, through events such as slow earthquakes and creep, to true seismicity (Fig. 1).

\section{Workshop Organization}

The Miyazaki workshop provided an overview of past, active, and planned drilling projects in diverse tectonic settings. The range of plate boundary fault systems was very well represented, including convergent (both subduction and collision) thrust-fault systems, divergent (rift) normal-fault systems, and transform strike-slip fault systems. Intraplate, relatively small-scale but active (and in some cases very destructive), faults are also under intensive study in projects reported on and discussed at the workshop. The workshop comprised three meeting days, all in plenary session, and a full-day field trip between the second and third meeting day to visit spectacular seaside exposures of the Nobeoka thrust fault near the town of Nobeoka. This thrust fault is interpreted as an exhumed formerly active plate boundary thrust fault at seismogenic depths in a subduction-related accretionary complex (Kondo et al., 2005). The field trip vividly illustrated the challenges of fault zone drilling, as scientists and engineers examined a zone of chaotically folded, fractured, and damaged rock tens of meters thick surrounding a fault core only tens of centimeters thick with even thinner slip surfaces emebedded within it (see cover illustration; Tsuji et al.; and Ujiie; this issue). These narrow zones and wider unstable rock areas would present a challenge as targets of drilling, core recovery, and downhole measurement.

Participants (see back cover) contributed to an agenda organized around a series of themes. The first day of the workshop was devoted to several presentations discussing the motivations for fault zone drilling, including how to get seismologists, fault geologists, and those of other interested disciplines working together using common terminology and ideas. It also featured overviews of the main recent and active drilling projects, summarized below, and of key topics such as fault zone structure, seismology, hydrology, and modeling of fault physics. The second day began with a session devoted to seismology, strain measurements of several forms, and remote geophysical detection of physical properties in and around faults. This was followed by a session focused on the structure and composition of fault zones from outcrops and borehole samples and logging. Each session was accompanied by plenary discussion, which ultimately led to the consensus recommendations described below. The third day was devoted to the field trip to the Nobeoka thrust, where fault structures were observed in outcrop. Finally, on the fourth day of the meeting, several presentations described newly proposed or emerging future projects, and then the rest of the day was devoted to technological challenges for sampling, sample handling, drilling and completion, and downhole measurements and monitoring. The workshop was closed out with an extended period of plenary discussion, highlighting many of the areas of future opportunity as well as challenges. Posters on many specific projects and topics related to all of these sessions were displayed for the duration of the meeting, and the contents of many are reflected in the extended abstracts of this volume. 


\begin{tabular}{|c|c|}
\hline $\begin{array}{l}\text { Earthquake cycle } \\
\alpha \text { - secular elastic loading } \\
\beta \text { - preseismicaccelerating slip } \\
\gamma \text {-coseismic slip } \\
\delta \text { - postseismicdecelerating slip }\end{array}$ & $\begin{array}{l}\text { Record of seismic cycling in } \\
\text { fault zones } \\
\square \text { Both fast and slow } \\
\text { deformation and recovery } \\
\text { features, e.g., friction melts } \\
\text { and solution seams } \\
\text { Important remaining } \\
\text { problems: } \\
\square \text { Partitioning of deformation } \\
\text { between damage zone and } \\
\text { core of fault for each phase of } \\
\text { cycle } \\
\square \text { Partitioning of slip between } \beta, \\
\gamma, \text { and } \delta \text { phases of earthquake } \\
\text { cycle as function of depth }\end{array}$ \\
\hline \multicolumn{2}{|c|}{ Figure 1. The earthquake cycle as a structural process (Chester, unpublished). } \\
\hline
\end{tabular}

Significant recent progress in understanding the mechanics of earthquakes and fault slip has been achieved through new seismological and geodetic observations, fault geology, laboratory experiments, and theory (Fig. 2). However, the factors controlling stable vs. unstable slip on faults remain poorly understood, impairing our ability to evaluate associated hazards. At present, there is no unified theory of fault slip to account for earthquake nucleation and propagation, nor to explain the mechanisms of strain across the spectrum of different deformation rates now being observed with durations ranging from seconds to years. Our understanding of the mechanics and dynamics of plate boundary faulting is severely limited by a lack of information on ambient conditions and mechanical properties of active faults at depth. A major present goal in earthquake mechanics research is thus direct in situ sampling and instrumentation by drilling into the seismogenic zone of active faults, including both interand intra-plate fault systems in many tectonic settings.

Here, we briefly summarize some of the key scientific motivations for engaging in fault zone drilling that were especially highlighted at the workshop. Two recently published reviews of fault zone drilling activity by Reches and Ito (2007) and Zoback et al. (2007) both discuss the principal specific scientific goals of recent, active, and planned projects in detail, and it would be redundant to duplicate them here.

Zoback et al. (2007) summarized the fundamental motivation well, writing: "It is currently impossible to differentiate between-or even adequately constrain-the numerous conceptual models of active faults proposed over the years (Fig. 3). For this reason, the Earth science community is left in the untenable position of having no generally accepted paradigm for the mechanical behavior of faults at depth." This fundamental igno-

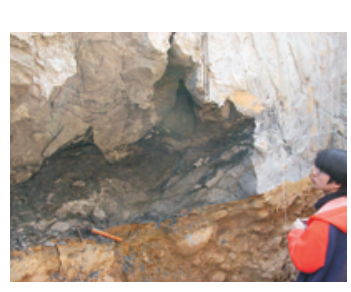

Fault outcrops and drill cores rance drives the research objectives of many of the projects touched on at this workshop. Some of the key questions include the following. What are the deformation mechanisms of fault slip in both aseismic and seismic conditions? Why is slip sometimes seismic, sometimes aseismic, and sometimes in an intermediate state, and what governs the transitions among these processes? How do earthquakes nucleate, and how does rupture grow and stop? Are there precursory phenomena in the fault or near field that indicate a preparatory phase to earthquake or slip nucleation? If so, can a prediction or early warning strategy based on borehole observation be developed? What are the processes governing tsunamigenic slip? What is the role of fluid content and fluid pressure in modulating faulting processes, especially during rapid seismic slip? How does permeability of the fault zone evolve interseismically and coseismically? What is the stress tensor in and around a fault zone throughout the earthquake cycle or other slip? What controls localization of slip vs. distributed strain in faulting? Fault zone drilling is justified by the need to shed light on these and related questions if we are to develop that paradigm for faults at depth.

Most, but not all, of the fault zone drilling efforts highlighted during the workshop focus on elucidating earthquake processes, though some have focused on aseismic faulting, particularly in accretionary prisms (Moore, this issue). The objectives and activities of the various fault zone drilling projects can be summarized as falling into three basic categories:

\section{Direct sampling of fault zone and surrounding rocks and} fluids: Acquiring samples (core, cuttings, and fluids) from the subsurface in a relatively pristine state for further study is a universal high priority (see Part 3 section this issue on Fault Zone Structure, Composition, and Physical Properties). The mineralogy, microstructure and fabric, mechanical properties, and fluid content and composition are all relevant to discovery of the physical processes involved in aseismic

\begin{tabular}{|llll|}
\hline $\begin{array}{l}\text { FAULT } \\
\text { STUDIES } \\
\text { Deformation } \\
\text { mechanisms } \\
\text { \& fluid flow } \\
\text { in fault zones }\end{array}$ & $\begin{array}{l}\text { EXPERI- } \\
\text { Mechanical \& transport } \\
\text { properties of faults }\end{array}$ & $\begin{array}{l}\text { THalyses of earthquake } \\
\text { generation processes based } \\
\text { on measured properties }\end{array}$ & $\begin{array}{l}\text { THEORY, } \\
\text { Dynamic fault motion } \\
\text { during earthquakes }\end{array}$ \\
\hline
\end{tabular}

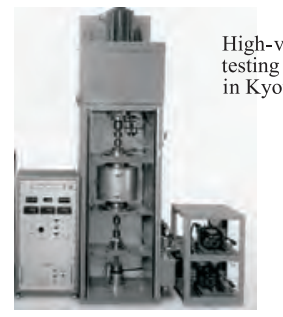

Reproduction of seismic fault motion

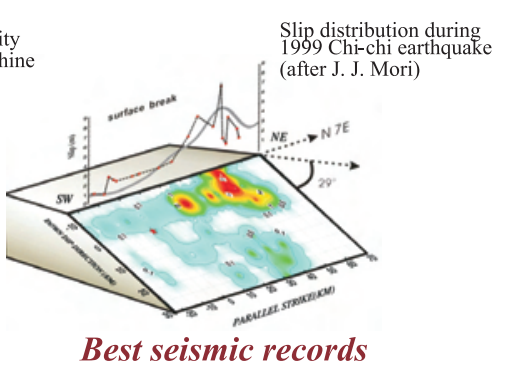

Best seismic records

Figure 2. A concept of integrated fault studies in field,laboratory experiment, theory and simulation, and seismic/geodetic observations on faulting and earthquakes (T. Shimamoto, unpublished). 


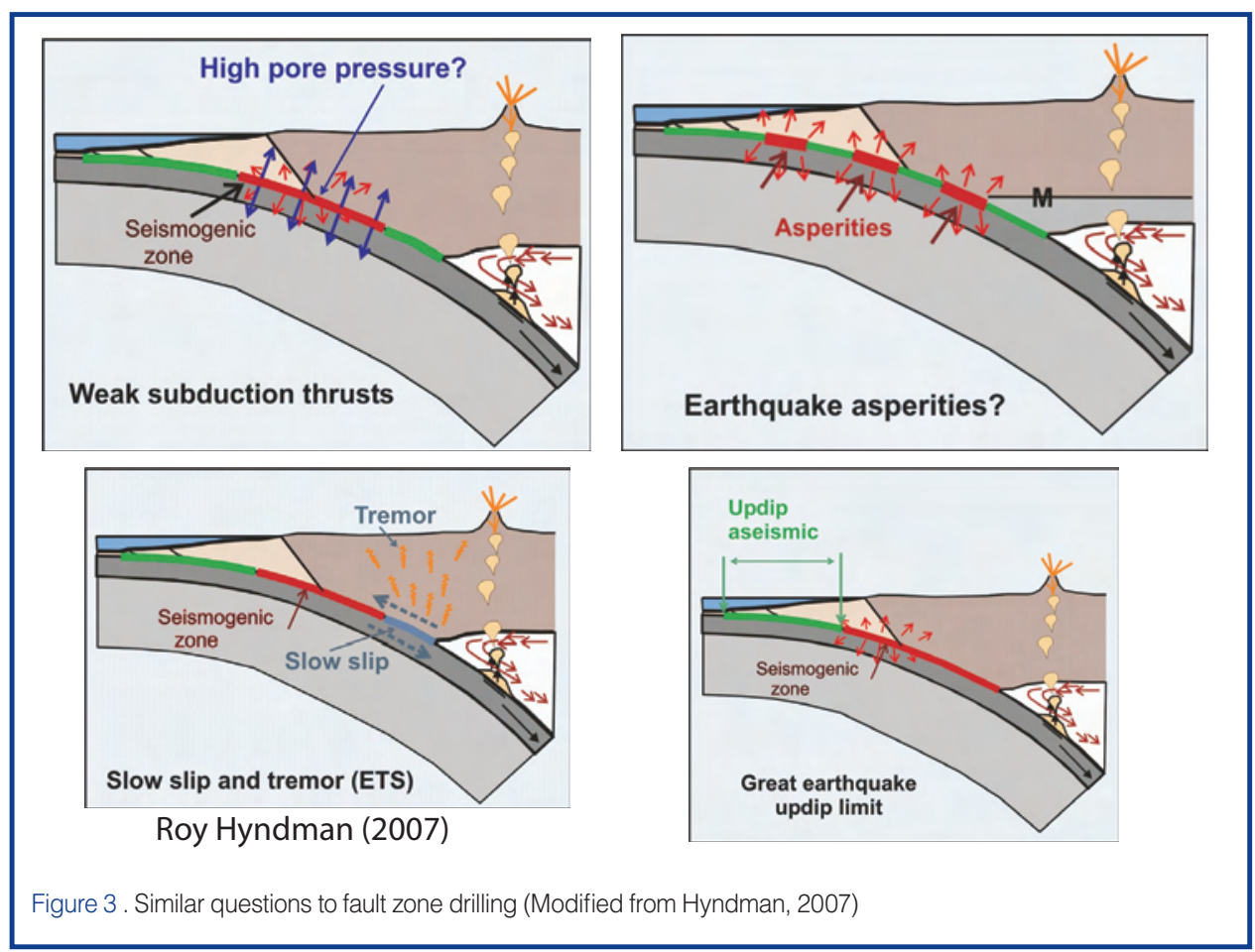

seismic preparation phase-before nucleation of a major event-that might be detectable through nearfield observations in the subsurface. Transient slip events, fault creep, and bursts of microseismicity may take place during the interseismic period on large faults and provide important information on mechanical process and constitutive properties. In other cases, such as deep mine fault drilling and seismicity studies, the monitoring is tied to active manipulation of the pore pressure and stress field, for a more explicit form of in situ experimentation (Ogasawara et al., this issue).

\section{Current and Completed Projects}

The workshop included presen-

and seismic faulting. Only samples obtained from in situ positions can unequivocally be associated with fault processes uncontaminated by later alteration. Samples provide material for geological, geochemical, and petrophysical analyses to deduce the record of fault processes in the rocks (including ephemeral properties derived from very recent slip in some cases, such as TCDP or Nojima drilling). They also provide ground-truth to calibrate remote-sensed geophysical measurements based on seismic velocity and reflectivity, resistivity, gravity, and other observations over much larger volumes of the crust surrounding the borehole.

\section{Conducting active tests or observations in situ in faults} through borehole access: Besides the samples obtained through drilling, the borehole itself is a window into the fault zone and the faulting process. Borehole logging for detection of physical properties and imaging of stratigraphy, fractures, breakouts, and other features; downhole experimentation such as hydrologic testing through the use of borehole seals (packers); and collection of fluid samples are all emphasized to varying degrees in these projects (e.g., Hickman et al.; and Ito, this issue).

\section{Monitoring the fault zone over time in borehole observato-} ries: Long-term access to and use of the boreholes are key elements of most of these projects, though they are limited in many cases by technical challenges or budget. Monitoring of seismic activity, temperature, the strain field, pore fluid pressure, and seismic velocity structure of the fault zone and surroundings are consensus objectives across most of these programs. Borehole-based observations can be complemented by surface instruments such as land-surface or ocean-bottom broadband seismometers. A key question in fault zone studies is whether there is any evidence for a pre- tations and exploration of virtually all of the major fault drilling projects worldwide in the past two decades. Most of these projects are represented by one or more papers in the accompanying extended abstract section. One interesting theme that emerges from this review is the following specific strengths associated with land-based and ocean-based drilling. ODP fault zone drilling at sea has been tightly integrated with high quality geophysical imaging (usually 3-D seismic reflection datasets that allow precise targeting), has made very productive use of logging-while-drilling (LWD) technology and cores by drilling multiple holes at the same location, and has deployed multiple sealed boreholes for hydrologic and other observations (Moore; Ranero; and Tobin and Kinoshita; this issue). The results include a great deal of quantitative information about the physical and hydrological properties of faults in relatively shallow (and aseismic) positions beneath the ocean floor in subduction zones. On land, by contrast, a major emphasis has been on sophisticated downhole experimentation and imaging, including seismology, hydraulic fracturing tests, breakout analysis, and more (Cornet; and Ellsworth et al., this issue). Land based boreholes have also obtained very high quality core in many cases, permitting detailed structural and petrological analyses of fault zone properties (Hung et al.; Lin et al.; Nielson; and Omura; this issue). It is therefore clear from the brief review below that oceanic and continental drilling studies of faults have been complementary operations to date, each advancing our understanding on different topics.

The section below is meant merely as a brief introduction to each area; an exhaustive review of the literature for each is beyond the scope of this paper. In roughly chronological order, the major projects discussed at the workshop were as follows. 
KTB Project, Germany: The Kontinentales Tiefbohrprogramm der Bundesrepublik Deutschland (KTB), or German Continental Deep Drilling Program, was drilled from 1990 to 1994 in southeastern Germany. It is one of the deepest drilled holes on Earth, having reached $9101 \mathrm{~m}$ below the surface (Emmermann and Lauterjung, 1997). While not primarily intended as a fault zone project, KTB drilling did cross a tectonically inactive thrust fault system in metamorphic crystalline rock. Drilling activity, including fluid circulation and hydraulic fracturing tests and other perturbations of the borehole environment, caused microseismic activity in the near-field to the borehole, permitting analysis of the in situ state of stress (Zoback et al., 1993), presence of fluids and hydrologic properties, and thermal properties of the continental crust in this region. Many techniques used in continental drilling were pioneered or refined during KTB drilling.

Barbados Accretionary Wedge, Atlantic Ocean (ODP 110, 156, 171A): The Barbados wedge was the focus of substantial effort during DSDP and ODP, aimed at understanding the faulting conditions, ambient pore fluid pressure (Fig. 4), and mechanics in a very low angle ( 2 degree dip) décollement thrust fault at the base of an accretionary wedge (see Moore, this issue). A high quality 3-D seismic survey (Shipley et al., 1994) imaged the décollement plane reflector in unprecedented detail, and served as the basis for targeting drilling into the $\sim 30-40$-m thick décollement zone in areas of contrasting reflection amplitude and character, all in the relatively shallow and presumed aseismic portion of the plate interface at the base of the accretionary wedge. Drilling and logging measurements made while drilling (LWD) demonstrated that the fault zone was a mechanically very weak interval with high excess pore fluid pressure and patchily distributed areas of anomalously high porosity (Moore et al., 1998). Installation of a borehole seal (CORK), downhole testing, and other studies at Sites 948 and 949 have shown that the fault zone has effective permeability that is strongly pressure dependent and varies over $\sim 4$ orders of magnitude with fluid pressure (Fisher, 2005; see also Saffer, this issue).

Nankai Trough Accretionary Wedge, Muroto Region, Western Pacific Ocean (ODP 131, 190, 196): Drilling by ODP of the central Nankai Trough region off Shikoku island also focused on the décollement zone at the outer toe of the accretionary deformation, and provided a detailed understanding of the mechanics of the fault zone (Moore et al., 2001). The 20-30$\mathrm{m}$-thick fault zone encountered at Sites 808 and 1174 is a zone of strong brittle fracture deformation that separates hydrologically distinct regimes above and below the fault; the footwall is at least partially sealed and pressurized with superhydrostatic pore fluid, limiting the effective normal stress that can actatthefaultplane (Screaton etal.,2002). Microstructural and fabric analysis established that the décollement zone represents a virtually total strain decoupling of the footwall beneath the detachment, with basinal stress and strain state, and the accretionary wedge in the hanging wall, with hetero- geneous and tectonically-enhanced strain (Byrne et al., 1993). These observations imply the décollement acts as a plane of very low shear strength during deformation. LWD measurements, especially resistivity and density data, suggest that the décollement fault has a core of compacted but fractured rock that is dilated in the high pore fluid pressure environment (Bourlange et al., 2003).

Nojima Fault Projects, Japan: Soon after the Kobe earthquake in 1995 (M6.9), several research teams drilled multiple boreholes into and across the shallow portion of the Nojima fault (the locus of that event) from $\sim 750 \mathrm{~m}$ to $\sim 1800 \mathrm{~m}$ depth (Ito et al., 1999; Omura, this issue,). Detailed compositional and structural analyses identified a narrow fault core of gouge and surrounding damage zone, with asymmetric structure in the footwall and hanging wall (Boullier et al., 2001; Fujimoto et al., 2001; Ito et al., 1996; Ohtani et al., 2001; Tanaka et al., 2001). Shear wave splitting studies of aftershocks showed a rapid evolution of fast direction after the earthquake, interpreted as evidence of fracture healing during a 12 month post-seismic period (Tadokoro and Ando, 2002). The preliminary results were collected in the special 2001 volume of The Island Arc. From repeated injection tests, permeability change with time was observed (Tadokoro et al., 2000). The structural properties (fault-zone width, shear wave velocity, and Qs) of the Nojima Fault were studied using the Love-wave-type fault-zone trapped waves (LTWs) recorded at two borehole seismic stations, which were con-

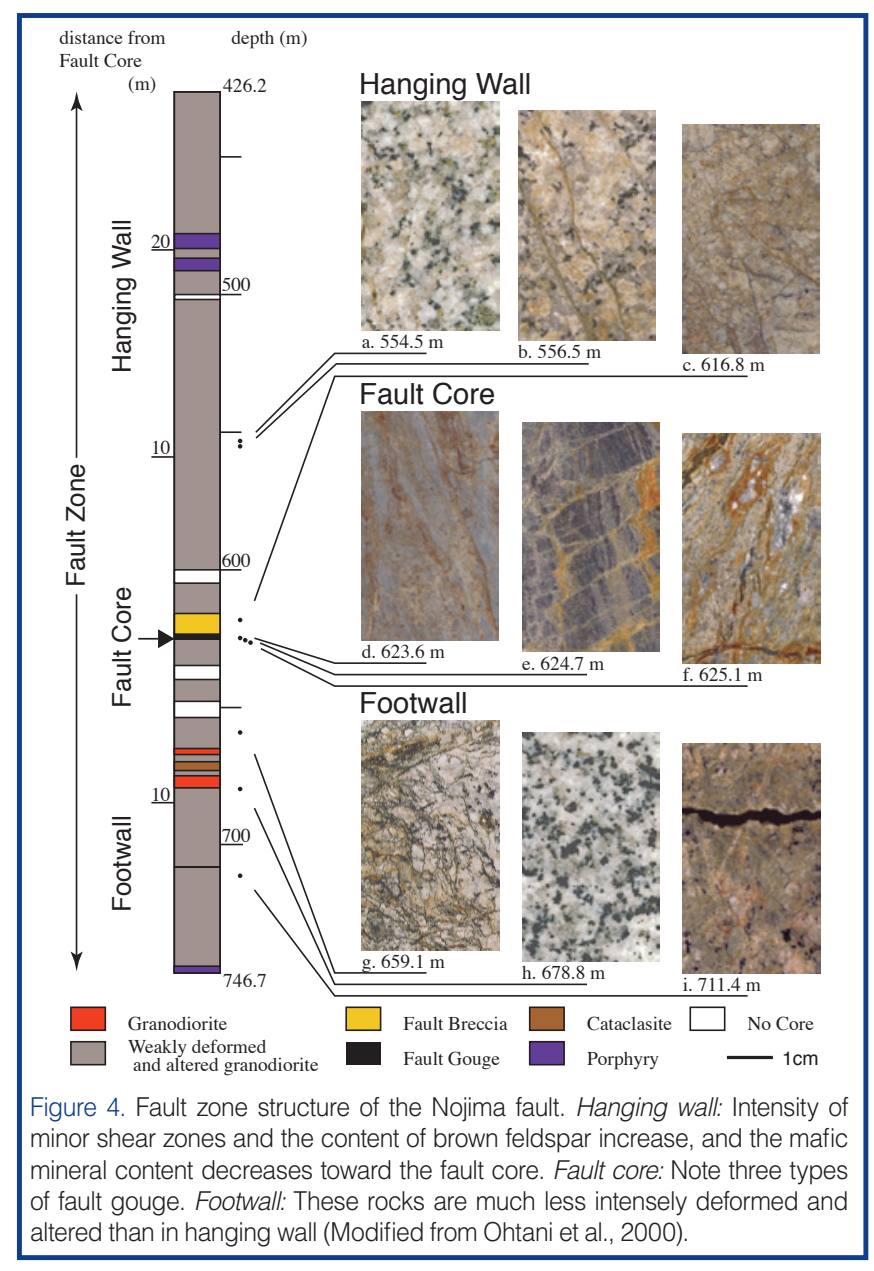


structed after the 1995 Kobe earthquake (Mizuno et al., 2007).

Costa Rica Convergent Margin, Nicoya Region, Eastern Pacific Ocean (ODP 170, 205): The Costa Rica margin off the Nicoya Peninsula in northwestern Costa Rica has been the site of two ODP expeditions that penetrated the décollement and other faults in two principal locations at depths of a few hundred meters below sea floor. Drilling demonstrated that the décollement fault overrides the subducting plate and all of the sedimentary section lying on top of it, such that the fault develops in a layer of extreme mechanical weakness made up of unconsolidated sediments (Silver et al., 2000). Structural studies and geochemical tracers of hydrological flow paths suggest that two strongly decoupled systems exist above and below the $\sim 20$-m-thick main fault zone, which acts simultaneously as a low-permeability barrier to cross fault flow and a high-permeability channel for along-fault flow (Tobin et al., 2001). Installation of a sealed borehole CORK during Leg 205 documented an apparently weakly overpressured décollement zone that exhibits temporal pressure excursions tied to apparent aseismic transients recorded geodetically on land (Davis and Villinger, 2006).

Corinth Rift Laboratory, Greece: The Gulf of Corinth is a location of back-arc extension within the Hellenic Arc system and is among the most seismically active areas of Europe (Cornet, this issue). The Corinth Rift Laboratory (CRL) Project drilled into the Aigion fault at $760 \mathrm{~m}$ depth and continued to $1000 \mathrm{~m}$, encountering cataclastic fault rocks in a karstic carbonate host-rock environment. The fault zone forms a strong hydrologic barrier with an associated pressure differential across it. Transients in pore pressure have been detected associated with remote earthquakes (Cornet et al., 2004). Plans for upcoming activities at CRL include near-term deployment of a string of high-frequency threecomponent geophones, packers, pressure transducers, tiltmeters, and thermistance meters across the fault penetration, and also a proposed 4.5-km-deep borehole to monitor pore pressure and other features of the seismogenic zone (Cornet, this issue).

Taiwan Chelungpu Drilling Project, Taiwan: The devastating 1999 M7.6 Chi-Chi earthquake in Taiwan was a thrust event in a collisional tectonic setting that exhibited very large slip (>10 m), including large surface displacements, on the Chelungpu fault. The principal objective of drilling was to sample the main slip surface or zone, if one could be identified, in the relatively short post-seismic period. The fault zone was drilled in 2004 and 2005 in an area of high-velocity large slip during the main shock, and crossed the fault zone and several hundred meters of the footwall in two adjacent holes (Ma et al., 2006). The main slip zone and several subsidiary (or older) fault cores were identified in the borehole at $1100 \mathrm{~m}$ depth (Hung et al., this issue). Studies of the fault gouge particle size, thickness, and composition have yielded quantitative estimates for the work done in forming gouge and damage (fracture energy), contributing to the understanding of energy budgets during earthquakes (Ma et al., 2006; Ma and Tanaka, this issue). Borehole hydrologic tests, temperature logging, and sample-based frictional experiments have all contributed to a tight integration of borehole derived in formation with seismological observations.

San Andreas Fault Observatory at Depth, California, U.S.A.: SAFOD targeted the San Andreas fault in a location at the transition from the locked zone that has ruptured repeatedly in $\mathrm{M} \sim 6$ earthquakes and the creeping segment to the north, where no large earthquakes have been observed. The location was chosen in part for the wealth of geophysical and other data generated during the decades-long Parkfield Experiment, where microseismic activity is very well located. The primary objectives included drilling into and across the San Andreas in a highly deviated $\left(\sim 55^{\circ}\right)$ hole to sample and $\log$ the fault zone environment and materials, and to place instruments into the nucleation zone of one or more repeating earthquakes of magnitude 1-2. Fault rock properties, stress, pore pressure, and temperature in situ, and near-field observations of the earthquake process are key objectives of the research program (Ellsworth et al., this issue). A pilot hole was drilled in 2002 (Hickman et al., 2004), then the main hole crossed and logged the SAF in 2005. A zone 230 m wide of low seismic velocity and density was detected at $\sim 3100 \mathrm{~m}$ below the surface, in host rock of siltstones, shales, and sandstones, interpreted as a broad damage zone (Schleicher et al.; Solum et al.; and Wiersberg and Erzinger; this issue). Within this zone, several narrower bands of apparently more concentrated deformation, and velocity reduction were detected, including locations where the casing installed in the borehole has deformed since installation, interpreted as due to active fault creep. Temperature measurements to date and deduced stress orientation (Boness and Zoback, 2006) are consistent with the paradigm of a weak fault in a strong crust. Phase 3 drilling in 2007 targets continuous coring of three holes across the active fault traces as sidetracks from the main hole, and will finish with installation of a monitoring system to be placed within the rupture patch of M2 earthquakes (Ellsworth et al.; Hickman et al.; this issue).

Fault Drilling in South African Mines (NELSAM and SeeSA): Deep gold mines in South Africa, among the deepest in the world, contain Precambrian age faults that have been reactivated and accessed by recent mining operations. These faults have been extensively used as natural laboratories for research programs by several groups from Japan, the U.S.A., Europe, and South Africa. Ogasawara et al. (2002; this issue) describe installation of strainmeters and arrays of accelerometers in faults in several different mines as part of the project Semi-controlled Earthquake-generation Experiments in South African deep gold mines (SeeSA). Large strains were recorded co-seismically during events of magnitude ranging from -1 to 3.0. Even the smallest events showed source processes as complex as those of larger earthquakes, and 
hypothesized accelerating strain phenomena preceding seismic events were generally not observed. The Natural Earthquake Laboratory in South African Mines project (NELSAM) has taken the strategy of densely instrumenting a network of faults in the TauTona mine (Reches, this issue) with accelerometers, seismometers, strainmeters, temperature sensors, creep-meters, an electromagnetic radiation system, and acoustic emissions detection, in anticipation of magnitude $\sim 2$ events expected to be induced by mining operations.

\section{Recent Progress in Technology}

In response to scientific objectives, recent progresses in drilling (Higuchi and Kobayashi, this issue), logging, coring and observatory (Ito, this issue) were reported at the workshop. It was emphasized that operational issues (such as penetration rate, hole stability, direction control, over/under pressure) and quality control on core and borehole conditions should be carefully considered according to the scientific objectives.

For the logging, the following new technologies are discussed:

- LWD is crucial to make measurements in unstable formations, and provides extremely fast a full set of data allowing full characterization before coring.

- Wireline logging has higher resolution and, in particular sonic tools, offers measurements not available in LWD (anisotropy, full waveforms, permeability).

- Care must be taken when using LWD, wireline logging, and coring in different holes.

- Future IODP vessels will allow measurements that were not available in ODP.

Designing the wells for life is a paradigm change in scientific drilling and involves permanent monitoring and well completion technologies. One of the advantages of borehole observatory is noise reduction (Fig. 5; Ito, this issue), and new technologies on deep borehole observatory have been developed.

\section{Planned Future Projects}

In this section, we summarize a few additional projects that have been funded or for which planning and/or pilot drilling activity is underway and advanced. Additional projects that are currently at the proposal stage are highlighted in the accompanying abstracts (Kopf and Bohnoff, this issue).

Nankai Trough Seismogenic Zone Project (NanTroSEIZE): As the December 2004 Sumatra earthquake and Indian Ocean tsunami so tragically demonstrated, large subduction earthquakes represent one of the greatest natural hazards on the planet. Accordingly, drilling into and instrumenting an active interplate seismogenic zone are very high priorities in the IODP Initial Science Plan (2001). Through a decadelong series of national and international workshops, a consensus emerged that the Nankai Trough is an ideal place to attempt drilling and monitoring of the seismogenic plate interface. Factors in this selection include the relatively shallow extent of large slip and moment release in the 1944 M8.1 Tonankai earthquake, the good quality imaging of targets for drilling through multichannel seismic reflection surveys (including 3-D), and the vast amount of geophysical study that has gone into characterizing this subduction zone (Tobin and Kinoshita, 2006). NanTroSEIZE targets a series of thrust fault crossings at depths below the sea floor from $<1000 \mathrm{~m}$ to $>5000 \mathrm{~m}$, to span the hypothesized up-dip transition from seismic to aseismic faulting processes. Coring, logging, downhole measurements, and the establishment of multiple instrumented boreholes spanning this zone are key objectives to address the questions of what controls the onset of seismogenic behavior with depth and how the faults behave spatially and temporally during interseismic and coseismic periods. The first phase of NanTroSEIZE drilling operations has now been scheduled for the fall of 2007 (Tobin and Kinoshita, this issue).

Costa Rica Seismogenesis Project (CRISP): CRISP is focused on access to the plate interface of a subduction zone where there is apparent "tectonic erosion" (the physical transfer of mass from the overriding plate to the downgoing plate at a subduction zone through thrust faulting). Erosional margins likely feature fault systems formed of protolith and fluid/heat conditions very different from accretionary margins such as Nankai (von Huene et al., 2004), because they may juxtapose crystalline crust of the upper plate with the downgoing basaltic slab and/or quantities of subducted sediment in the seismogenic zone. The CRISP-proposed project to IODP aims to drill first into the shallow portion of the plate

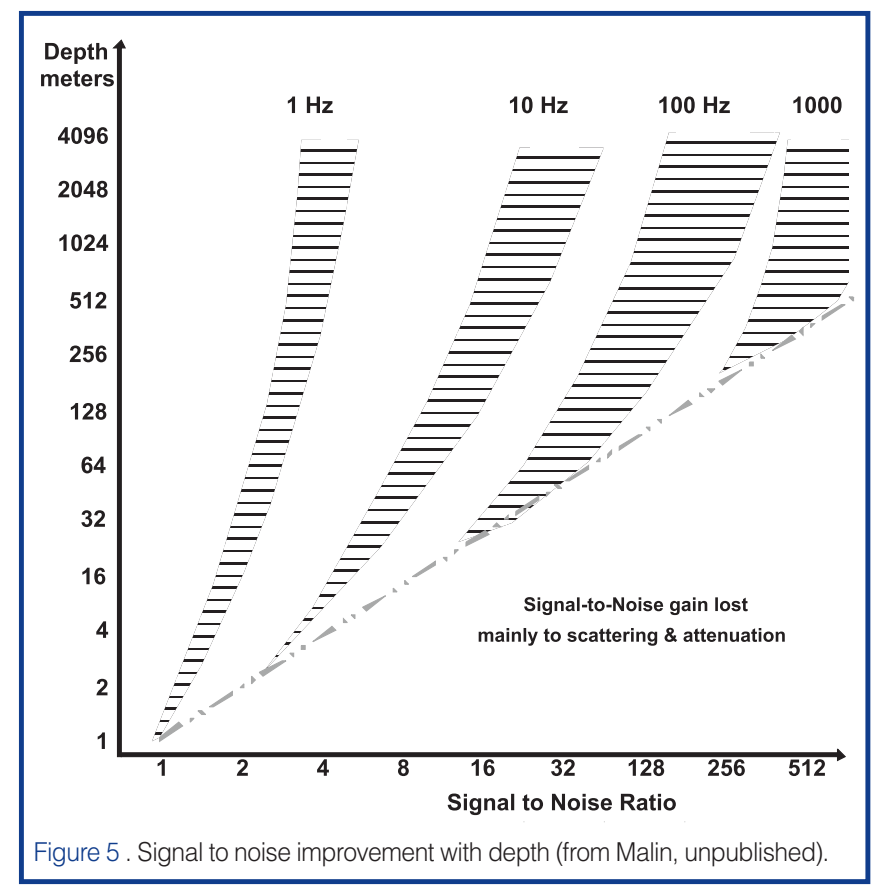


interface at $1-3 \mathrm{~km}$ below the sea floor, to sample the rock and fluid inputs and outputs to and from the seismogenic plate boundary, then in a later phase to drill to depths of $\sim 7 \mathrm{~km}$ below the sea floor, into the slip region of a 2002 magnitude 6.4 earthquake (Ranero et al., this issue).

Proposed North Anatolian Fault (NAF) Drilling: The North Anatolian fault is a strike-slip plate bounding continental fault that represents the greatest known seismic hazard to life and property in Europe (Dresen et al., this issue). This fault separates the Anatolian block from Eurasia, and has produced a devastating series of $\mathrm{M} \sim 7$ earthquakes in the past century, most recently the Izmit and Düzce quakes of 1999. The fault zone extends through the bed of the Marmara Sea near Istanbul, a location of identified seismic gap on the NAF. Coulomb stress analysis suggests that the 1999 earthquakes transferred positive stress change to this offshore segment, and an estimated probability of a major $\mathrm{M} \sim 7$ earthquake is $35 \%-70 \%$ in the next 30 years (Parsons, 2004). Dresen et al (this issue) propose an ICDP project involving a 2000-mdeep borehole to be drilled from an island in the near vicinity of the NAF to monitor seismicity, stress and stress changes, heat, and fluid flow. The goal is a monitoring system to better understand the temporal evolution and interseismic behavior of the NAF, with an eye also toward elucidating seismic hazards to the millions of inhabitants of the city of Istanbul and surrounding regions.

\section{Outcomes of the Workshop- Recommendations for Future Efforts}

Exploration at this workshop identified a host of topics and issues related to the science and technology of fault zone drilling. A common theme of these projects is that they seek to acquire three basic types of data: (1) studies of samples, including cores, cuttings, and fluids; (2) "spot" downhole measurements, including wireline and LWD/MWD logging, packer systems and other downhole testers, and borehole/ casing surveys; and (3) long-term monitoring data, including seismicity, strain and tilt, temperature, and continuous fluid sampling.

All of these areas were the subject of extensive discussion during the workshop. The most essential conclusion was that the Fault Zone Drilling Workshop was in a sense an introductory meeting -individuals working on the many IODP, ICDP, national, and other projects came together to identify common themes and challenges. The dialogue has started and has already led to enhanced interaction among the various scientific constituencies in the time since the workshop was held. The most useful way forward would be for IODP and ICDP to take the sponsorship role to make sure that dialogues continue on a number of key, specific areas in the future. Before and after the 2006 workshop, the economic environment for mounting ambitious drilling efforts has steadily worsened, from the standpoint of business and funding of high-cost, high-risk science in several countries.
Nevertheless, we suggest that IODP and ICDP can realize greater efficiency and success in future operations by leading efforts to combine force and expertise in new approaches to fault zone drilling.

Specific Recommendations: A number of recommendations for future efforts emerged during the numerous plenary discussions held throughout the workshop, as well as through the more informal interactions during poster sessions, evenings, and the field trip. These recommendations in some cases were for new driving questions and new strategies for subsurface access to faults; others were of a more technical or organizational nature.

The following overarching recommendations emerged:

- $\quad$ IODP and ICDP are urged to engage in joint efforts to develop optimal drilling techniques and drilling/casing/completion technologies specific to the fault zone environment.

- Through focused workshops, IODP and ICDP and the community should develop or document "best practices" statements for coring systems, core handling, and core orientation and for cuttings and fluids.

- Information exchange between IODP/ICDP/other drilling communities should be strengthened.

- The community should prioritize the development of plan(s) for a rapid drilling response to a suitable earthquake, on national and/or international levels.

- Sensor and deployment systems for monitoring should be identified/developed that are robust at temperatures of $120^{\circ} \mathrm{C}-160^{\circ} \mathrm{C}$ or greater (and have low power consumption for oceanic settings).

- New fault zone drilling proposals should be fostered through workshops networking with existing teams.

Grouping together several of these recommendations into themes, the motivation behind each and the specific recommendations as workshop outcomes are as follows.

1. Follow up with smaller working-group workshops on specific technical topics: The workshop identified many specific areas where new approaches and new technologies are either needed or have been developed for some projects but not yet widely adopted. We recommend that future joint efforts of IODP and ICDP include focused, small-team meetings to develop detailed "best-practices" for each area. Example topics for such working groups might be as broad as "Site Characterization" and as specific as "Core Orientation Methods". Other suggested areas for focus include: (1) improvements to core and fluid handling, such as developing more sophisticated approaches to capturing ephemeral properties in core, dealing with broken or fragile fault core, performing more scientific measurements using cuttings and drill mud, developing best practices for drilling fluid composition for scientific drilling, as deep land drilling and riser drilling at sea become more prevalent; (2) develop- 
ing improved site characterization methods including optimal arrays and methods for earthquake location; (3) careful attention to downhole measurements such as hydrologic and stress testing, weighing value of data vs. risks to the borehole; (4) developing best practices for a host of drilling techniques/technologies for the fault zone environment, including casing strategies, mud weight balancing to optimize borehole stability, and directional control (vertical and deviated); and (5) development of completion and long-term monitoring best practices (see below in this section).

One challenge to developing these workshops is that many of the principal scientists and drilling/measurement experts are involved in one or more of the major current projects and are simply spread too thin to lead such efforts. This leads to an overwhelming recommendation-expand the scientific and technical interest group for fault zone drilling and foster new teams and new team members. As activity has increased, such a growth in the pool of scientists has been occurring in Japan, the U.S.A., Europe, and Taiwan. This must continue to be encouraged through high-profile meetings, publications, and other venues.

\section{Enhance cross-communication among active and emerg-} ing projects: Because fault drilling projects are necessarily regional and often nationally supported, they require an explicit effort to keep lines of communication open. In particular, there are two principal organizations that support largescale and international efforts at drilling into faults: IODP and ICDP. These two organizations are separated by sea level, an essentially meaningless boundary in terms of the scientific motivation for drilling faults, yet drilling on land vs. at sea requires different platforms and drilling technologies. Workshop participants perceived a continued division at times between the activities of these two organizations, in part because of different organizational structures and systems. Clearly, however, overcoming the considerable technical challenges of carrying out ambitious drilling and casing, logging, or especially long-term monitoring (for examples, see Prevedel, this issue) would greatly benefit from a much tighter cooperation between IODP and ICDP, as well as national organizations (such as DOSECC). One widely endorsed recommendation was to develop industry/academia fault zone drilling advisory panels for technical issues such as drilling and completion strategies, and development of long-term monitoring instrumentation. Further recommendations include standardization of the engineering process for development of new coring methods, logging instruments, and monitoring systems. For example, the benefits of standard borehole seismometer strings were highlighted by two presentations (e.g., Stephen, this issue), so that each team spends less time "reinventing the wheel."

We endorse the recommendation for IODP and ICDP to intensify the exchange of information on technology, and to establish a common advisory or support panel for fault zone drilling.
3. Develop long-term monitoring systems and strategies capable of performing in the fault zone subsurface environment: The discussion of strategies for long-term monitoring system deployment was among the liveliest of the workshop. Participants generally agreed that monitoring over time is an absolutely essential aspect of studies in fault physics, since so many key processes are transitory or time-dependent in some way. Key parameters to monitor include seismicity, seismic velocity structure, strain and/or tilt, pore fluid pressure, temperature, and pore fluid chemistry. The fault zone environment at depth-where both temperature and pressure are greatly elevated, fluids may be corrosive, and return access is likely to be difficult or impossible-necessitates careful attention to monitoring schemes. Several key general practices emerged from this discussion. The principal one is to design for a long-term robust lifespan of the borehole as an observatory. Deep fault zone boreholes are large investments of capital and labor and must produce data for many years to realize their full potential. Thus, simple sensors are best; passive, non-powered instruments (e.g., geophones) should be preferred when possible. Some advocated maximizing use of passive instruments on the outside of installed casings, based on the logic that some form of measurement is better than none at all, and even if they fail, outside-casing instruments do not obstruct access to the interior of the borehole for other measurements. Redundancy was highlighted as an important objective, since individual sensors are prone to failure. The question of cementing in certain instruments, such as broadband seismometers and strainmeters, brought out a strong debate. On one hand, these instruments require very stable installations to work for years, favoring cementing in open holes. On the other hand, cementing them in blocks access to the hole for other instruments and may make it difficult or impossible to replace instruments that have failed. The choice depends on the balance of objectives unique to each project.

Workshop participants identified an urgent need for instruments and sensors robust for long periods of time at elevated temperatures and pressures. Lifespan is traded against stability at high temperatures in particular, such that a particular instrument might have a five-year life at $80^{\circ} \mathrm{C}$, but only a six-month life at $120^{\circ} \mathrm{C}$, for example. Broadband seismometers for installations above $\sim 100^{\circ} \mathrm{C}$ do not exist, and accelerometers, fiber optic sensors, and other alternatives do not have acceptable resolution or absolute precision. These roadblocks are common to all projects, land or sea, so one recommendation from this workshop is that IODP and ICDP develop joint efforts in long-term monitoring system development. A joint working group or panel would be ideal.

\section{Explore the potential for a rapid-response drilling plan:} This is the most specific recommendation, but it is necessary because such a plan would require a new approach to planning for drilling. A number of workshop participants emphasized the scientific merit of drilling into a fault soon after slip during a large earthquake in order to measure the transient 
signal of frictional heating and other properties before they decay (Kano et al.; Mori; this issue). A goal of drilling in weeks to months (rather than years) post-event was recommended. Participants agreed that a candidate earthquake would have magnitude of roughly 6 to 7 or greater, would be well recorded locally, would have significant fault slip in the upper few thousand meters subsurface, and would be located in a region easily accessible for drilling. The most significant challenge is that a rapid-response drilling program would require (a) a well developed plan that is focused and has clear objectives, yet is generic enough to apply to any earthquake and (b) funding in place in advance, with an agreed-upon set of criteria for initiating the plan when a suitable earthquake occurs. In addition, there has to be a carefully thought out technical plan to mobilize a rig on relatively short notice. These requirements contrast sharply with the typical process of developing a specific drilling program over many years. One additional challenge to overcome is that such a plan would work best if candidate events in many, or at least more than one, country could be considered, so as to shorten the likely wait for a suitable event, but funding agencies' national interest and issues with permits might make it difficult to make this a strongly international effort. Despite these potentially formidable obstacles, the sense of the workshop was that this initiative should be explored. Since the Miyazaki workshop, an ICDP workshop proposal has been submitted to further explore the rapid response concept.

\section{Extended Abstracts in This Volume}

The collection of volunteered extended abstracts that follows this section represents a snapshot of many of the themes highlighted in both presentations and posters during the workshop. It is not intended to comprehensively capture the range of subjects discussed during the workshop, nor the full extent of current endeavor in this field. Nevertheless, the thirty-six abstracts here represent examples of current efforts in many areas. We have chosen to group them roughly into sections with the themes of (1) Scientific Motivations for Fault Zone Drilling, containing abstracts dealing with the broader issues that can be best or only addressed through drilling, and including (2) overviews of many of the major projects; (3) Fault Zone Structure, Composition, and Physical Properties, with papers principally on lithology, mineralogy, structural fabrics, and seismic and hydrologic properties; (4) The Physics of Earthquake Rupture, concerned with nearfield seismology and fault physics as addressed through modeling and laboratory experimentation; and (5) Technological Challenges of Drilling, Testing, Sampling, and Monitoring in Fault Zones, which deals with new techniques for core handling and sampling, borehole instrumentation, downhole active testing of formation properties, logging, and drilling and completion operations in the fault zone environment. These reflect the key themes and challenges discussed in the section above. It is our intention that publication of this volume will stimulate new collaborations and links among developing research efforts on land and at sea, and also will encourage ambitious new programs to tackle these challenges. The improved understanding of fault processes will depend on a multi-pronged, multi-disciplinary approach using new tools and collecting novel types of data.

\section{Concluding Remarks}

A principal objective of the Miyazaki joint workshop was to bring together the land-based and ocean-based fault zone communities for an exchange of information and ideas, and an exploration of the commonalities and differences in working in these very different environments. On this aspect the workshop can only be judged a resounding success. New collaborations began during the four days of the meeting, and tighter integration of projects has begun. For example, an ICDP workshop has now been scheduled for summer 2007 to explore an on-land extension of the NanTroSEIZE offshore transect (see http://www.icdp-online.org/contenido/icdp/ front_content.php?client=29\&idcat=309\&lang=28\&idart=19 31). The Mediterranean Ridge proposal (Kopf and Bohnoff, this issue) is another example of integrated land-sea drilling plans. All the projects, past or future, reviewed at this workshop have unique motivations, strategies for success, advantages and challenges, and it is likely that only by advancing on many of these simultaneously will the fault zone research community make substantial progress in coming years.

This workshop established a single global community of researchers on drilling-based fault studies. With two well established, highly visible and successful organizations in place (ICDP and IODP) to support scientists' efforts, it is our hope and expectation that the legacy of the workshop will be a dynamic, multi-disciplinary, and integrated research program in coming years.

\section{Acknowledgements}

We are very grateful for the support of both the Integrated Ocean Drilling Program (IODP) and the International Continental Drilling Project (ICDP) for their generous cosponsorship of the costs of holding this workshop. In particular, we thank Dr. Manik Talwani of IODP for sparking the idea to hold a joint workshop, and Dr. Ulrich Harms of ICDP for unstinting support. The staff at the Phoenix SunGaia Hotel in Miyazaki provided excellent support in all respects. The most essential person for the success of the Fault Zone Drilling workshop was certainly Dr. Kelly Kryc of IODP-MI, who carried out the workshop organization with great professionalism, patience, and good humor. Production of this workshop report white paper and special volume of Scientific Drilling would not have taken place without the hard work and supreme patience of Emanuel Soeding, Mika Saido, and Hans-Christian Larsen of the journal, and we are indebted to them for their efforts. 


\section{References}

Boness, N. and Zoback, M.D., 2006. A multi-scale study of the mechanisms controlling shear velocity anisotropy in the San Andreas Fault Observatory at Depth. Geophysics, 7(5):F131F146, doi:10.1190/1.2231107.

Boullier, A-M., Ohtani, T., Fujimoto, K., Ito, H., and Dubois, M., 2001. Fluid inclusions in pseudotachylytes from the Nojima fault, Japan. J. Geophys. Res., 106:21965-21977.

Bourlange, S., Henry, P., Moore, J.C., Mikada, H., and Klaus, A., 2003. Fracture porosity in the décollement zone of Nankai accretionary wedge using Logging While Drilling resistivity data. Earth Planet. Sci. Lett., 209:103-112, doi:10.1016/S0012-821X(03)00082-7.

Byrne, T., Maltman, A., Stephenson, E., Soh, W., and Knipe, R., 1993. Deformation structures and fluid flow in the toe region of the Nankai accretionary prism. In Hill, I.A., Taira, A., Firth, J.V., et al., Proc. ODP, Sci. Results, 131: College Station, Texas (Ocean Drilling Program), 83-101.

Cornet, F.H., Bernard, P., and Moretti, I., 2004. The Corinth Rift Laboratory. Comp. Rend. Geosci., 336:235-241, doi:10.1016/ j. crte.2004.02.001.

Davis, E.E. and Villinger, H.W., 2006. Transient formation fluid pressures and temperatures in the Costa Rica forearc prism and subducting oceanic basement: CORK monitoring at ODP Sites 1253 and 1255. Earth Planet. Sci. Lett., 245(1-2):232244. doi:10.1016/j.epsl.2006.02.042.

Earth Oceans and Life: Integrated Ocean Drilling Program Initial Science Plan, 2003-2013, 2001. International Working Group Support Office, Washington, D.C., 110 p., Available from: http://www.iodp.org/isp

Emmermann, R. and Lauterjung, J., 1997. The German Continental Deep Drilling Program KTB: Overview and major results. J. Geophys. Res., 102:18179-18201, doi:10.1029/96JB03945.

Fisher, A., 2005. Marine hydrogeology: recent accomplishments and future opportunities. Hydrogeol. J., 13:69-97, doi:10.1007/s10040-004-0400-y.

Fujimoto, K., Tanaka, H., Higuchi, T., Tomida, N., Ohtani, T., and Ito, H., 2001. Alteration and mass transfer inferred from the Hirabayashi GSJ drill penetrating the Nojima fault, Japan. The Island Arc, 10:401-410.

Hickman, S., Zoback, M.D., and Ellsworth, W.E., 2004. Introduction to special section: Preparing for the San Andreas Fault Observatory at Depth. Geophys. Res. Lett.,. 31:L12S01, doi:10.1029/20040GL20688.

Hyndman, R.D., 2007. The seismogenic zone of subduction thrust faults: what we know and don’t know. In The Seismogenic Zone of Subduction Thrust Faults, Eds.: Dixon, T.H. and Moore, C., Columbia University Press, 15-40.

Ito,H., Kuwahara, Y., Miyazaki, T., Nishizawa, O., Kiguchi, T., Fujimoto, K., Ohtani, T., Tanaka, H., Higuchi, T., Agar, S., Brie, A., and Yamamoto, H., 1996. Structure and physical properties of the Nojima fault by the active fault drilling, Butsuri-Tansa, 49, 522-535.

Ito, H., Fujimoto, K., Tanaka, H., and Lockner, D., 1999. Proceedings of the international workshop on the Nojima fault core and borehole data analysis. Geological Survey of Japan Interim
Report No. EQ/00/1, USGS Open-File 895 Report 000-129.

Kondo, H., Kimura, G., Masago, H., Ohmori-Ikehara, K., Kitamura, Y., Ikesawa, E., Sakaguchi, A., Yamaguchi, A., and Okamoto, S., 2005. Deformation and fluid flow of a major out-ofsequence thrust located at seismogenic depth in an accretionary complex: Nobeoka Thrust in the Shimanto Belt, Kyushu, Japan. Tectonics, 24:TC6008, doi:10.1029/2004TC001655.

Ma, K.-F., Tanaka, H., Song, S.-R., Wang, C.-Y., Hung, J.-H., Tsai, Y.-B., Mori, J., Song, Y.-F., Yeh, E.-C., Soh, W., Sone, H., Kuo, L.W., and Wu, H.-Y., 2006. Slip zone and energetics of a large earthquake from the Taiwan Chelungpu-fault Drilling Project. Nature, 444:473-476, doi:10.1038/nature05253.

Mizuno, T., Kuwahara, Y., Ito, H., and Nishigami, K., 2007. Spatial variations in fault-zone structure along the Nojima fault, central Japan, as inferred from borehole observations of fault-zone trapped waves. Bull. Seism. Soc. Amer., in press.

Moore, G.F., Taira, A., Klaus, A., Becker, L., Boeckel, B., Cragg, A., Dean, A., Fergusson, C.L., Henry, P., Hirano, S., Hisamitsu, T., Hunze, S., Kastner, M., Maltman, A.J., Morgan, J.K., Murakami, Y., Saffer, D.M., Sánchez-Gómez, M., Screaton, E.J., Smith, D.C., Spivack, A.J., Steurer, J., Tobin, H.J., Ujiie, K., Underwood, M.B., and Wilson, M., 2001. New insights into deformation and fluid flow processes in the Nankai Trough Accretionary Prism: results of Ocean Drilling Program Leg 190. Geochem. Geophys. Geosyst., 2, doi:10.129/2001GC000166.

Moore, J.C., Klaus, A., Bangs, N.L., Bekins, B., Buecker, C.J., Brueckmann, W., Erickson, S.N., Hansen, O., Horton, T., Ireland, P., Major, C.O., Moore, G.F., Peacock, S., Saito, S., Screaton, E.J., Shimeld, J.W., Stauffer, P.H., Taymaz, T., Teas, P.A., and Tokunaga, T., 1998. Consolidation patterns during initiation and evolution of a plate-boundary décollement zone: Northern Barbados accretionary prism. Geology, 26:811-814, doi:10.1130/0091-7613(1998)026<0811: CPDIAE $>2.3 . \mathrm{CO} ; 2$.

Ogasawara, H., Yanagidani, T., and Ando, M., 2002. Seismogenic process monitoring. Proceedings of a Joint Japan-Poland Symposium on Mining and Experimental Seismology, Kyoto, Japan (A.A. Balkema), 414 pp.

Ohtani, T., Fujimoto, K., Ito, H., Tanaka, H., Higuchi, T., Tomida, N., 2000. Fault rocks and past to recent fluid characteristics from the borehole survey of the Nojima fault ruptured in the 1995 Kobe earthquake, southwest Japan. J. Geophys. Res., 105, 16161-16171.

Ohtani, T., Tanaka, H., Fujimoto, K., Higuchi, T., Tomida, N., and Ito, H., 2001. Internal structure of the Nojima fault zone from the Hirabayashi GSJ drill core. The Island Arc, 10:392-400.

Oshiman, N., Shimamoto, T., Takemura, K., and Wibberley, C.A.J., 2001. Nojima Fault Zone Probe. The Island Arc, 10:195-505.

Parsons, T., 2004. Recalculated probability of $M \geq 7$ earthquakes beneath the Sea of Marmara, Turkey. J. Geophys. Res., 109: B05304, doi:10.1029/2003JB002667.

Reches, Z. and Ito, H., 2007. Scientific drilling of active faults: Past and future. In Harms, U., Koeberl, C., and Zoback, M.D. (Eds.), Continental Scientific Drilling: A Decade of Progress and Challenges for the Future, Heidelberg, Germany 
(Springer), doi:10.1007/978-3-540-68778-8_6.

Screaton, E., Saffer, D., Henry, P., Hunze, S., and the Leg 190 Scientific Party, 2002. Porosity loss within the underthrust sediments of the Nankai accretionary complex: Implications for overpressures. Geology, 30(1):19-22, doi:10.1130/00917613(2002)030<0019:PLWTUS >2.0.CO;2.

Shipley, T.H., Moore, G.F., Bangs, N.L., Moore, J.C., and Stoffa, P.L., 1994. Seismically inferred dilatancy distribution, northern Barbados Ridge décollement: Implications for fluid migrationandfaultstrength.Geology,22:411-414, doi:10.1130/00917613(1994)022<0411:SIDDNB>2.3.CO;2.

Silver, E.A., Kastner, M., Fisher, A.T., Morris, J., McIntosh, K.D., and Saffer, D.M., 2000. Fluid flow paths in the Middle America Trench and Costa Rica margin. Geology, 28:679-682, doi:10.1130/0091-7613(2000)28<679:FFPITM>2.0.CO;2.

Tadokoro, K. and Ando, M., 2002. Evidence for rapid fault healing derived from temporal changes in S wave splitting, Geophys. Res. Lett., 29(4), 1047, doi:10.1029/2001GL013644.

Tadokoro, K., Ando, M., and Nishigami, K., 2000. Induced earthquakes accompanying the water injection experiment at the Nojima fault zone, Japan: Seismicity and its migration. J. Geophys. Res., 105:6089-6104, doi:10.1029/1999JB900416.

Tanaka, H., Fujimoto, K., Ohtani, T., and Ito, H., 2001. Structural and chemical characterization of shear zones in the freshly activated Nojima fault, Awaji Island, southwest Japan.J. Geophys. Res., 106:8789-8810.

Tobin, H. and Kinoshita, M., 2006. NanTroSEIZE: the IODP Nankai Trough seismogenic zone experiment. Sci. Drill., 2:23-27, doi:10.2204/iodp.sd.2.06.2006.

Tobin, H., Vannuchi, P., and Meschede, M., 2001. Structure, inferred mechanical properties, and implications for fluid transport in the décollement zone, Costa Rica convergent margin. Geology,29:907-910, doi:10.1130/0091-7613(2001)029<0907: SIMPAI $>2.0$. CO;2.

von Huene, R., Ranero, C.R., and Vannucchi, P., 2004. A model for subduction erosion. Geology, 32:913-916, doi:10.1130/G20563.1.

Zoback, M., Hickman, H., and Ellsworth, W., 2006. Structure and properties of the San Andreas fault in central California: Preliminary results from the SAFOD experiment. Geophys. Res. Abstr., 8:02474.

Zoback, M.D., Apel, R., Baumgartner, J., Brudy, M., Emmermann, R., Engeser, B., Kessels, W., Fuchs, K., Rischmuller, H., Rummel, F., and Vernik, L., 1993. Upper-crustal strength inferred from stress measurements to $6 \mathrm{~km}$ depth in the KTB borehole. Nature, 365:633-634, doi:10.1038/365633a0.

Zoback, M.D., Hickman, S., and Ellsworth, W., 2007. The role of fault zone drilling, 2007, In Kanamori, H., and Schubert, G. (Eds.), Earthquake Seismology - Treatise on Geophysics. Amsterdam, The Netherlands (Elsevier), in press.

\section{Authors}

Harold Tobin, Associate Professor, Department of Geology and Geophysics, University of Wisconsin-Madison, 1215 West Dayton Street, Madison, Wis. 53706, U.S.A., e-mail: htobin@wisc.edu.

Hisao Ito, Center for Deep Earth Exploration (CDEX) Japan Agency for Marine-Earth Science and Technology (JAMSTEC), 3173-25 Showa-machi, Kanazawa-ku, Yokohama, Kanagawa, 236-0001, Japan.

Jan Behrmann, Marine Geodynamics, IFM-GEOMAR, Wischhofstr. 1-3, 24148, Kiel, Germany.

Steve Hickman, U.S. Geological Survey, MS977, 345 Middlefield Road, Menlo Park, Calif., 94025, U.S.A.

Gaku Kimura, Department of Earth and Planetary Sciences, Graduate School of Science, The University of Tokyo, 7-3-1 Hongo, Bunkyo-ku, Tokyo, 113-0033, Japan. 